\title{
The Covid-19: Problem-Solving and Survival Way of Low-Income Families
}

\author{
Guntur Trimulyono ${ }^{1 *}$ Muslimin Ibrahim ${ }^{1}$ Mahanani Tri Asri ${ }^{1}$ Isnawati $^{1}$ Lisa Lisdiana $^{1}$ \\ ${ }^{I}$ Department of Biology, Universitas Negeri Surabaya, Surabaya, East Java, Indonesia \\ *Corresponding author.Email: gunturtrimulyono@unesa.ac.id
}

\begin{abstract}
The Indonesian government has declared the Coronavirus Disease 2019 (Covid-19) virus outbreak as a nonnatural national disaster. A healthy behavior, social, and physical distancing should be implemented to break the chain of the Covid-19 virus transmission. This research aimed to determine the problem-solving and survival way of low-income families during the Covid-19 pandemic. Data was collected using a questionnaire that contains multiple-choice and open questions distributed to 84 respondents. Then, data were analyzed descriptively. The results indicated most low-income families aware of the Covid-19 threat and consumed traditional herbs or vitamins as prevention. Nevertheless, they depend on their monthly income to live. Thus, $44.05 \%$ of respondents still do their outdoor activities. Amongst $94.05 \%$ of respondents knew the WHO protocol to prevent virus transmission, such as wearing a mask, maintaining the physical distance, washing hands with soap, and wearing gloves. Despite their awareness of the Covid-19 threat, more than $70 \%$ of respondents would not seek medical attention if they feel unwell. Instead, they bought medicine in the market. Even though most of the respondents aware of the Covid-19 threat and perform a healthy lifestyle, they still lack an understanding of the importance of medical treatment. Thus, community service is needed near the future to gain awareness of the importance of medical treatment.
\end{abstract}

Keywords: Covid-19, low-income families, healthy lifestyle

\section{INTRODUCTION}

The world is currently facing a new coronavirus (SARS-CoV-2) pandemic that causes Coronavirus Disease 2019 (Covid-19). This virus emerged around December 2019 and then spread to various countries in the world. The World Health Organization (WHO) announced the existence of this virus on December 31, 2019, which initially detected in Wuhan, China [1]. Meanwhile, in Indonesia, the government announced the first discovery of a patient suffering from Covid-19 on March 2, 2020 [2].

The Covid-19 virus outbreak declared as a national nonnatural disaster by the Indonesian government [3]. Based on data from the national Covid-19 Task Force on August 7, 2020, 121,226 positive cases of Covid-19 has been confirmed, with 5,593 of them dying and 77,557 successfully recovered [4]. The symptoms of Covid-19 are varied, ranging from mild to severe symptoms. The main clinical symptoms in patients infected with Covid19 are fever $>38^{\circ} \mathrm{C}$, coughing, and breathing difficulties. Besides, it accompanied by severe shortness of breath, fatigue, myalgia, gastrointestinal symptoms such as diarrhea, and other respiratory symptoms. But, some patients show mild symptoms without fever [1].

Currently, a drug to treat Covid-19 nor a vaccine for Covid-19 has not been found yet. It has caused concern in the community so that it requires efforts to prevent the spread of the Covid-19 virus. The efforts made by the government to break the chain of the Covid-19 virus transmission include calls for clean and healthy living habits, social distancing, and physical distancing. The President of the Republic of Indonesia issued Government Regulation Number 21 concerning Large-Scale Social Restrictions. The government has implemented LargeScale Social Restrictions in several areas to prevent the spread of the outbreak and the emergence of more victims. These efforts have greatly influenced the pattern of life in society, related to social relations and the 
economic aspects of the community. Several institutions, agencies, and industries implement Work from Home (WFH), and several people experience an impact on their economy.

The Covid-19 virus pandemic has an impact on the national economy. According to the Minister of Finance of the Republic of Indonesia, it affects the national economy in all sectors, from labor to industrial performance. A total of more than 1.5 million workers are being sent home $(90 \%)$ and laid off $(10 \%)$ [5]. The impact of the Covid-19 virus pandemic is felt by the lower middle class, some of whom are now living without work and income, while others are trying hard to maintain their businesses [6]. The Covid-19 virus pandemic affects lowincome families harshly. Low-income families are people who have limited purchasing power and need government support to get a house [7].

Each community has their strategy to solve problems and to survive during the Covid-19 pandemic according to their abilities. With all the limitations experienced during the Covid-19 virus pandemic, it is important to know how the most affected community can solve problems to survive during the Covid-19 virus pandemic. This research aims to determine problem-solving patterns and how low-income families survive during the Covid-19 virus pandemic. This research will give an insightful overview of problem-solving and ways of community survival that can be used to increase knowledge and references for the community in the future.

\section{METHOD}

This research was conducted with a survey method using a questionnaire filled in by respondents from lowincome families. The sampling method used was purposive sampling with research targets is low-income families located in the Surabaya City and Jombang Regency, East Java. The research was carried out in the following steps

\subsection{Preparation}

In this step, we collected the information related to low-income families and developed the materials for the questionnaires. The questionnaires comprised questions related to respondents' knowledge regarding the Covid-19 virus pandemic, economic conditions, how to fulfill daily needs during the Covid-19 virus pandemic, activities to support health, and survival strategies to prevent the exposure to Covid-19 virus, and actions taken in case of health problems. The questionnaire developed was in the form of multiple-choice and open questions to explore information about problem-solving patterns and survival strategies of low-income families during the Covid-19 pandemic.

\subsection{Questionnaire Validation}

The developed questionnaire is reviewed internally in the team to get improvements. Then, the questionnaire form is assessed by the expert validators to get an assessment. The results of the questionnaire validation are scores/numbers which state the validity of the developed questionnaire.

\subsection{Data Collection and Analysis}

The validated questionnaires were distributed to respondents, which categorized as low-income families. The respondents filled out the questionnaires directly or online by using Google form. Then, collected data were analyzed descriptively to picture the problem-solving patterns and survival strategies of low-income families during the Covid-19 pandemic.

\section{RESULT AND DISCUSSION}

The subjects in this study were low-income families that defined as people who earn below the regional minimum wage. The questionnaire was filled out by 84 respondents with various backgrounds.

Based on the answers given by respondents, 92\% knew about the Covid-19 virus pandemic (Fig. 1). It indicated that information related to Covid-19 were welldistributed among society through various mass media and social media. The society's understanding of the Covid-19 virus pandemic is one of the keys to prevent virus transmission because it will increase awareness to participate actively in efforts to prevent further spread.

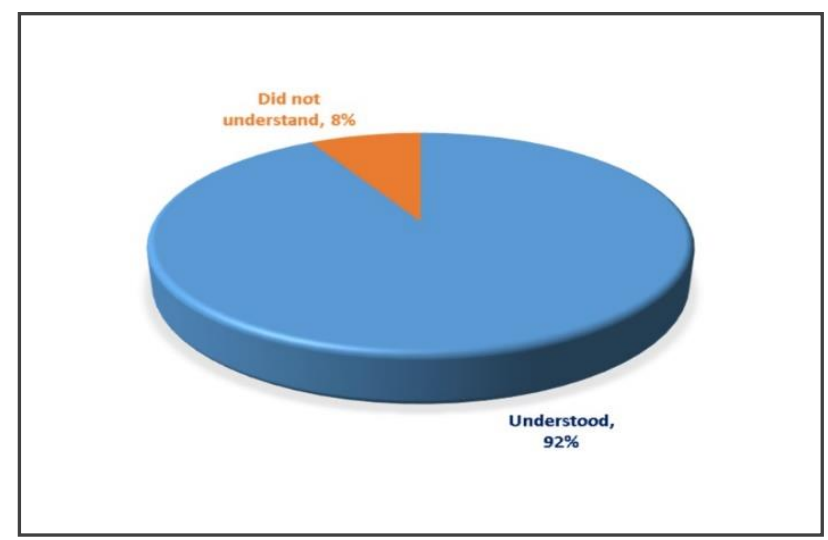

Figure 1. Respondent' knowledge about Covid-19 virus pandemic 
Another study in Jakarta found that $83 \%$ of their respondents have good knowledge of Covid-19 prevention [8]. Consistently, as many as $69.35 \%$ of Nggrogah society also had a good understanding of Covid-19 [9]. Online media, social media, and television have a significant role on society's understanding of Covid-19 [10].

In the questionnaire, 51 respondents $(60.71 \%)$ stated that their income was not enough to meet their daily needs, while the remaining 33 respondents $(39.29 \%)$ stated theirs was sufficient. Most of the respondents depend on their income so that they have to work and did outdoor activities (44.05\%). Outdoor activities and social interactions can increase the possibility of being exposed to the Covid-19 virus. Therefore, knowledge and implementation of the WHO protocols to prevent virus transmission was needed during outdoor activities. This finding was consistent with another research, which found the respondents $(86.2 \%)$ still carried out outdoor activities during the Covid-19 pandemic [10]

Generally, respondents knew about the WHO health protocol to prevent virus transmission. Only $3.57 \%$ did not know about it. From several health protocols recommended by $\mathrm{WHO}$, most respondents have carried out physical distancing, wearing masks, and washing hands with soap (Fig. 2). However, only 33 respondents implemented the protocol using gloves (Fig. 2). Public awareness to implement the WHO health protocol is a way to prevent Covid-19 virus transmission.

A previous study indicated a relationship between public knowledge of Covid-19 and the awareness to wear masks [8][9]. The Covid-19 pandemic also changed public habit. Currently, most people adopting a healthy lifestyle, such as frequently washing hands [11].

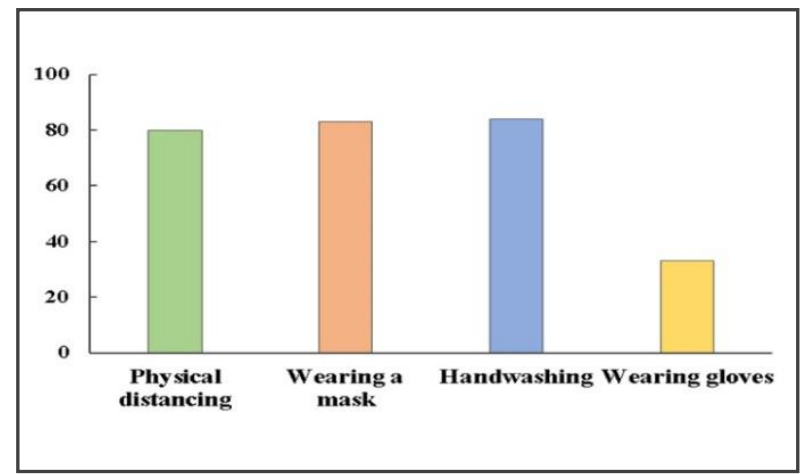

Figure 2. Implementation of the WHO health protocol by respondent

As previously explained, most respondents only depend on their income. Therefore, they need a strategy to meet the needs of their daily lives. The problem-solving chosen by respondents included finding a side job
$(21.43 \%)$ and keep working by implemented the WHO protocol (27.38\%) (Fig. 3).

Respondents' awareness of Covid-19 made $46.43 \%$ of respondents take supplements to keep their health. The supplements consumed were in the form of vitamins (51.11\%) and traditional herbal medicine (20\%) (Fig. 4). Apart from taking supplements, respondents also practice a healthy lifestyle in the form of exercise $(66.67 \%)$ to

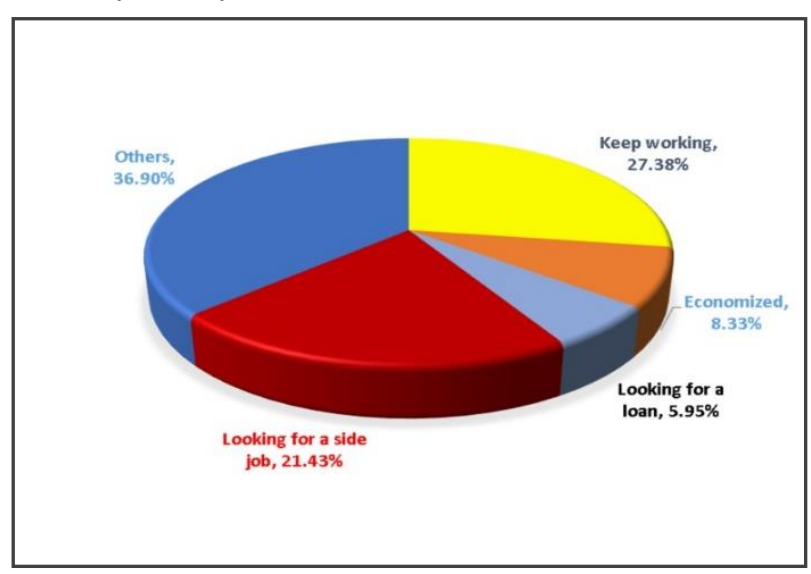

maintain body fitness.

Figure 3. The problem-solving of low-income families during Covid-19 virus pandemic to meet the needs of their daily lives

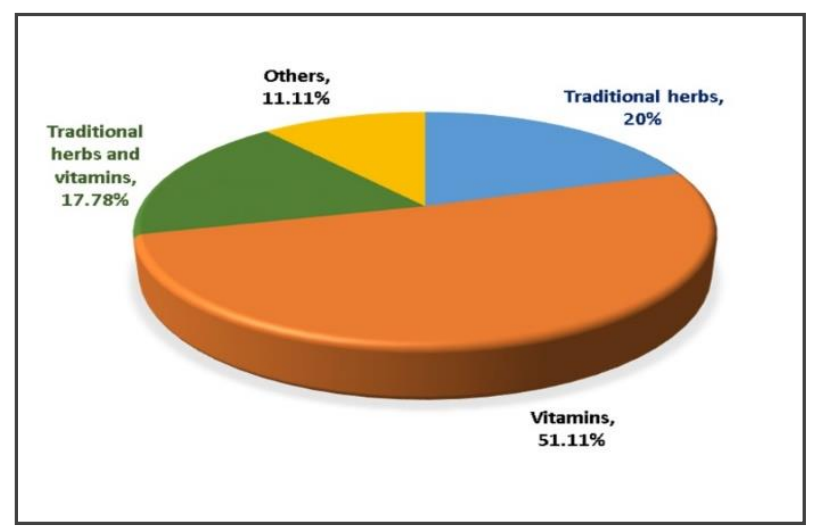

Figure 4. The problem-solving of low-income families to maintain their health

In this study, the questionnaire also explored information about the actions taken in case of health problems. As many as $71.44 \%$ of respondents will only buy medicine if they feel unwell, $11.90 \%$ will seek treatment at health facilities, while $7.14 \%$ choose to use the services of a practitioner if they feel unwell (Fig 5). Others $3.57 \%$ of respondents did both buying medicine and going to a health facility, while $1.19 \%$ of the respondents would both buy medicine and go to a practitioner (Fig. 5). The rest of the respondents with a percentage of $1.19 \%$ chose to get rest (Fig. 5). This 
finding indicated a lack understanding of the importance of medical treatment on the low-income society.

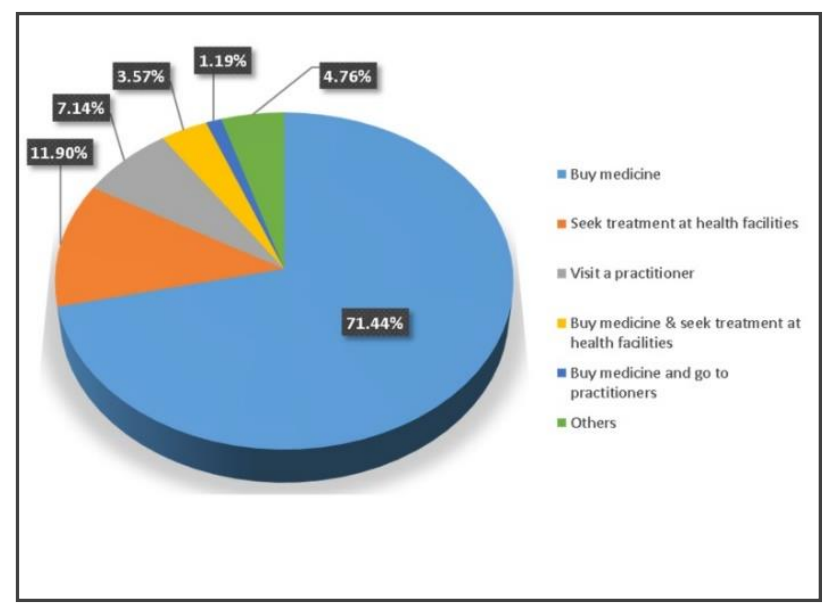

Figure 5 The problem-solving of low-income families in case of facing a health problem

\section{Conclusion}

Based on the discussion, it can be concluded that most people aware of the dangers of Covid-19 and implemented health protocols in their daily activities. In order to fulfill their daily needs, low-income families sustain their activities by implementing health protocols. As their survival way, they take supplements and do exercise.

\section{ACKNOWLEDGMENT}

Acknowledgment was addressed to Universitas Negeri Surabaya who have funded this research through PNBP funds.

\section{REFERENCES}

[1] Yuliana, Coronavirus Disease (Covid-19); Sebuah Tinjauan Literatur. Wellnes and Healthy Magazine Volume 2, Nomor 1, Februari 2020, pp. 187 - 192.

[2] Isbaniah, F., et al., Pedoman Pencegahan dan Pengendalian Coronaviruses Diseases (Covid-19).
Direktorat Jenderal Pencegahan dan Pengendalian Penyakit (P2P). Kementerian Kesehatan RI, 2020.

[3] Zahrotunnimah, Langkah Taktis Pemerintah Daerah Dalam Pencegahan Penyebaran Virus Corona Covid19 di Indonesia. SALAM: Jurnal Sosial dan Budaya Syar-I. Vol 7, No. 3, 2020.

[4] www.covid19.go.id. Accessed on 7 Agustus 2020

[5] Pebrianto, F., Sri Mulyani Beberkan 8 Dampak Covid-19 Sampai Hari ini. Tempo.co. Jumat, 17 April $2020 \quad 15: 49 \quad$ WIB https://bisnis.tempo.co/read/1332613/sri-mulyanibeberkan-8-dampak-covid-19-sampai-hari-ini. Accessed on 26 Mei 2020.

[6] Febryan, Cerita Dampak Corona di Masyarakat Ekonomi Kelas Bawah. REPUBLIKA.co.id. Kamis $16 \quad$ Apr $2020 \quad 13: 30 \quad$ WIB https://republika.co.id/berita/q8vbf9328/ceritadampak-corona-di-masyarakat-ekonomi-kelasbawah. Accessed on 26 Mei 2020.

[7] Peraturan Menteri Pekerjaan Umum Dan Perumahan Rakyat Republik Indonesia Nomor 10/PRT/M/2019.

[8] Utami RA, Mose RE, Martini, Pengetahuan, Sikap dan Keterampilan Masyarakat dalam Pencegahan Covid-19 di Provinsi DKI Jakarta. Jurnal Kesehatan Holistic. Vol 4, No 2, Juli 2020, pp. 68 - 77.

[9] Sari DP, 'Atiqoh NS, Hubungan Antara Pengetahuan Masyarakat dengan Kepatuhan Penggunaan Masker sebagai Upaya Pencegahan Penyakit Covid-19 di Ngronggah. Jurnal Ilmiah Rekam Medis dan Informatika Kesehatan, Vol 10, No 1, Februari 2020, pp. $52-55$.

[10] Widyaningrum N, Putri YD, Wilopo, Gambaran Penerapan Physical Distancing sebagai Upaya Menekan Persebaran Covid-19 di Provinsi Daerah Istimewa Yogyakarta. Nusantara: Jurnal Ilmu Pengetahuan Sosial. Vol 7, No 2, 2020, pp. $470-$ 481 .

[11] Adawiyah DPR, Sholichati I. Kebijakan PSBB Pemerintah Kota Surabaya dalam Menyegah Penyebaran Virus Covid-19. SAHAFA Journal of Islamic Communication. Vol. 3, No. 1, July 2020, pp. $61-72$. 